\title{
MYANMAR'S CULTURAL DIMENSIONS: EXPLORING THE RELATIONSHIP AMONG THE SOCIAL IDENTITY, ATTITUDES TOWARDS GLOBALISATION AND PREFERENCES OF MYANMAR CONSUMERS IN YANGON
}

\author{
Alana Rudkin* \\ School of Communication, American University, \\ 4400 Massachusetts Ave., Washington, DC 20016, United States \\ E-mail: rudkina@gmail.com \\ Joseph Erba** \\ William Allen White School of Journalism and Mass Communications, \\ University of Kansas, 1435 Jayhawk Blvd., Lawrence, KS 66045, United States \\ E-mail: erba@ku.edu
}

Published online: 15 January 2018

To cite this article: Rudkin, A. and Erba, J. 2018. Myanmar's cultural dimensions: Exploring the relationship among the social identity, attitudes towards globalisation and preferences of Myanmar consumers in Yangon. International Journal of Asia Pacific Studies 14 (1): 191-226, https://doi.org/10.21315/ijaps2018.14.1.8

To link to this article: https://doi.org/10.21315/ijaps2018.14.1.8

\begin{abstract}
Myanmar is transitioning to an open market economy, but very little is known about Myanmar consumers and their attitudes towards globalisation. Using Hofstede's cultural dimensions and social identity theory, this study sheds light on the role Myanmar consumers' cultural values and social identity play in consumer preferences. This study also explores the relationship between Myanmar identity and consumers' perceptions of products based on country of origin and attitudes towards globalisation. Results from a cross-sectional survey of Myanmar consumers in Yangon $(N=268)$ reveal that consumers displayed cultural traits similar to the ones from their neighbouring Southeast Asian countries. In addition, Myanmar consumers in Yangon do not express any particular consumer animosity towards products from other countries and seem open to globalisation. Findings provide
\end{abstract}


further insights into Myanmar culture and how to effectively communicate with Myanmar consumers.

Keywords: Myanmar, cultural dimensions, social identity, consumer preference, globalisation

\section{INTRODUCTION}

Myanmar, Southeast Asia's fifth largest nation (Population Reference Bureau 2015), is undergoing a historic transition towards democracy. Prior to 2011, Myanmar had been closed off to much of the Western world. Economic and trade sanctions had limited Western companies from doing business there since the 1990s. However, political and economic reforms have brought Myanmar out of decades of self-imposed isolation, and many countries, including the United States and the European Union member states, have lifted their sanctions on the country. This has allowed for the emergence of an open market economy in Myanmar, and many multinational companies are looking to expand their businesses in Southeast Asia's last "frontier market" (Dubyne 2010). More recently, in March 2016, Myanmar elected its first civilian president, ending a military dictatorship that lasted more than 50 years. With a population of 52.1 million and a rising demand for Western goods, Myanmar's demographic profile is a strong indication of the growth prospects available to international consumer goods companies. However, very little research exists on Myanmar's consumer market and consumer behaviour (Lwin et al. 2006; Rarick and Nickerson 2009).

This study investigates the influence of cultural values and social identity on the preferences of Myanmar consumers in Yangon. More specifically, this study seeks to understand the role Myanmar identity plays on consumers' perceptions of products based on country of origin and attitudes towards globalisation. Culture and identity are intimately related and equally important when it comes to understanding consumer behaviour and developing effective marketing strategies to communicate cross-culturally. The findings help advance the customer-oriented approach to international marketing enabling multinational companies to present their products and services in a culturally relevant manner to audiences in Yangon.

This study utilises Geert Hofstede's (2001) well-established cultural dimensions to gain important macro-level insights into Myanmar culture, values, and norms. These insights provide the foundation and data necessary to understand how Myanmar culture may influence the purchasing preferences of 
Myanmar consumers in Yangon. Furthermore, a basic awareness of Myanmar cultural values helps to determine the types of marketing strategies and tactics most likely to resonate with consumers. However, recognising the limitations of a macro-level cultural analysis in understanding individual consumption activity, this study is grounded in social identity theory, which allows for a more micro-level examination of the relationship between consumers' social identity and their consumer preferences and attitudes towards globalisation. Furthermore, this study explores the influence of products' country of origin on consumer preferences.

This paper presents the result of a cross-sectional survey of Myanmar consumers in Yangon. It begins by introducing the theoretical framework of the study, which reposes on Hofstede's cultural dimensions and social identity theory. This is followed by a discussion on the role a product's country of origin can play on consumers' preferences and may lead to consumer ethnocentrism or animosity. Next, the historical and cultural contexts of Myanmar are briefly addressed, before focusing more attention on Myanmar's recent socioeconomic developments. The study's research questions and hypotheses are formally presented, with a detailed description of the study's methods. Results are discussed in terms of participants' cultural dimensions, social identities, consumer preferences, and attitude towards globalisation. Lastly, practical and theoretical implications of the study, as well as limitations and future research, are considered.

\section{LITERATURE REVIEW}

As globalisation has led many companies to expand their businesses across borders, the need for understanding cultural influences on consumer preference and effective ways to communicate in diverse markets has become increasingly important. Intercultural or cross-cultural communication is an interdisciplinary field of research that "studies how people understand each other across group boundaries of various sorts: national, geographical, ethnic, occupational, class or gender" (Kramsch 2001: 201). Researchers dedicated to the study of intercultural communication seek to understand how people from different cultures act, communicate, and perceive the world around them (Philipsen 2003). Understanding the distinct features of a particular culture and its influence on individuals' identity will provide marketing practitioners with a deeper appreciation for how and why consumers arrive at their purchasing decisions. Indeed, for a business to successfully market and sell its products 
internationally, it is important marketers understand the fundamental values, norms, and communication techniques used to accomplish daily affairs in the target market.

\section{Hofstede's Cultural Dimensions}

Exploring the values and norms of diverse cultures provides important theoretical and practical insights necessary to successfully carry out an international marketing campaign. Recognising a need for cross-cultural comparison, a number of scholars have proposed various methods for operationalising and analysing culture (e.g., Hall 1963; 1981; Hofstede 1980; 1991; 2001; Lenartowicz and Roth 1999; Schwartz 1992; 1994), which have been applied in international marketing studies. The most well-known and widely used framework for comparing national cultures was developed by Dutch social psychologist Geert Hofstede (1980; 1991).

Through a statistical analysis of 116,000 questionnaires on work-related values from over 60,000 IBM employees in 70 countries, Hofstede proposed that cultures are comparable on four distinct dimensions: Power Distance, Individualism/Collectivism, Masculinity/Femininity, and Uncertainty Avoidance (Soares et al. 2006: 280). These dimensions are based on four fundamental problems which society faces: 1) the relationship between the individual and the group; 2) social inequality; 3) social implications of gender; and 4) handling of uncertainty inherent in economic and social processes (Steenkamp 2001: 30). In the late 1980s, on the basis of research by Canadian psychologist Michael Harris Bond who centred on Confucian values, a fifth dimension was added: Long-Term versus Short-Term Orientation (Hofstede and Bond 1988; see also Hofstede 1991 2001). Subsequent research by Bulgarian scholar Michael Minkov using data from the World Values Survey (Minkov 2007) allowed for the addition of a sixth dimension: Indulgence versus Restraint (Hofstede et al. 2010).

Hofstede's original four dimensions are most pertinent to this study on the influences of culture and identity on consumer preferences. Indeed, while the latter two dimensions are important for understanding certain cultural characteristics, there is little research on their applicability to international marketing and consumer behaviour (Van Everdingen and Waarts 2003; Venaik et al. 2013). Therefore, this study only incorporates the following four dimensions into its research: Power Distance, Individualism/Collectivism, Masculinity/Femininity, and Uncertainty Avoidance. 
Hofstede developed a country index scale, with equal one-point intervals ranging from zero to one hundred for each dimension, and based on his research, ranked countries based on where they fit within the scale for each category. Therefore, on any given dimensions, the scores are absolute, thus making it easy to compare and rank each dimension across countries (Hofstede, 1983). For example, a country with a score of 78 on the power distance dimension would have twice the power distance of one with a score of 39. In the following section, Hofstede's four cultural dimensions are briefly described using his online "country comparison" tool (geert-hofstede.com) to reveal how the United States ranks in comparison to Asian countries, and the consequent implications on international marketing and consumer preference. The numerical value associated with each country's score on Hofstede's cultural index scale will be provided in parentheses $(\mathrm{X} / 100)$ next to the country's name.

Power Distance: Power distance can be thought of as the extent to which less powerful members of a society accept and expect that power is distributed unequally. A high score on this dimension indicates a society in which social inequalities are understood as the norm and therefore accepted, while a low score on this dimension indicates a society with a greater level of respect for social equality.

A society's level of power distance has important implications for international marketing and consumer preference formation. For example, in a multinational study on the dimensions of humour in advertising, Alden et al. (1993) found that 63 percent of humorous television advertisements in Thailand (64/100) and South Korea (60/100), countries with high power distance, contain characters of unequal status, versus only 29 percent in the United States (40/100) and Germany (35/100), countries with low power distance. In fact, Mooij (2010) suggests the use of humour itself in advertising is more prevalent in countries with low power distance.

Social-economic hierarchy is another aspect of power distance which influences consumer behaviour. The more a society emphasises economic status differences, the more likely consumers will be to purchase products that are symbolic of those differences (Wuthnow et al. 1984). In most Asian societies, affluence is a relatively new phenomenon, and one's position in society is determined largely by economic advancement. Therefore, displaying wealth through material goods and brands has become an important social marker (Wong and Ahuvia 1998). Mooij and Hofstede (2011) agree that, "in high power distance cultures, one's social status must be clear so that others can show proper respect. Global brands serve that purpose" (182). 
Individualism vs. Collectivism: The fundamental matter addressed by the individualism-collectivism dimension deals with the extent to which individuals are integrated into groups (family, community, country, etc.). Individualistic cultures value personal achievement and responsibility to oneself and immediate family, while collectivist cultures value group loyalty and social relationships over individual sentiments.

The concept of self as developed in the individualistic Western world includes "the person as an autonomous entity with a distinctive set of attributes, qualities, or processes" (Mooij and Hofstede 2011: 183). In most Western-individualistic_cultures, such as the United States (91/100), people tend to assess the identity of self and others based on personality traits and other individual characteristics such as age and occupation, and material symbols (Belk 1984). On the other hand, in collectivist cultures like Indonesia $(14 / 100)$ or Thailand (20/100), "the self cannot be separated from others and the surrounding social context, so the self is an interdependent entity that is part of an encompassing social relationship" (Mooij and Hofstede 2011: 183).

Consumers attribute personalities to brands that fit their own cultural values, not the values of the brand's producer (Foscht et al. 2008; Mooji and Hofstede 2011). People in individualistic cultures typically prefer low-context communication (explicit, concise), while those in collectivist cultures tend to prefer high-context communication (indirect, strong emphasis on trust and relationships). For instance, Han and Shavitt (1994) found that when benefits to the individual are highlighted in advertisements, Europeans and Americans are more persuaded to buy a laundry detergent than when benefits to the family are highlighted; the reverse is true for Koreans, who prefer laundry detergent marketed with communal rather than individual-value focus. Zhang (2010) explains, this can be thought of as "a cultural congruency effect because a certain ad appeal is congruent or coincides with one's cultural orientation and, hence, creates a stronger preference" (71). Similarly, the collectivistic orientation of Koreans is related to the importance they place on a company's corporate social responsibility efforts (Bae and Kim 2013).

Masculinity vs. Femininity: A high score (masculine) on this dimension suggests that a society is driven by achievement, competition, and success; while a low score (feminine) suggests that a society values quality of life and happiness over monetary or material success. In masculine cultures, such as the United States (62/100) "performance and achievement are highly valued; and achievement must be demonstrated, so status brands or products such as jewellery are important to show one's success" (De Mooij 2004: 247). In contrast, feminine cultures, such as Thailand (32/100) or Sri Lanka (10/100), 
success is measured in quality of life (health, happiness, etc.), and standing out from the crowd is not admirable (Hofstede 2011).

Cross-cultural content-analytic studies of magazine and television advertisements have consistently shown that the portrayals of women and men's roles in advertising differ by culture (Moon and Chen 2002; Sengupta 1995; Wiles and Tjernlund 1991). Through a content analysis of gender role portrayals in 400 web advertisements in the United States and South Korea, An and Kim (2007) found "a greater percentage of Korean ads featured characters in relationship themes, featured women as a main character, and portrayed them in family and recreational roles" (181). In terms of international marketing, these results validate the use of Hofstede's masculine vs. feminine cultural dimension when determining appropriate advertising appeal related to gender roles.

Uncertainty Avoidance: Uncertainty avoidance measures the degree to which people feel threatened by uncertainty and ambiguity. Ahigh score on this dimension indicates uncertainty-avoiding cultures and a low score indicates uncertainty-accepting cultures. People in uncertainty-avoiding cultures, such as Japan (92/100), tend to engage in behaviour and activities which are familiar and understood as being socially acceptable. There is a sense of unspoken rules and regulations in place, which help maintain order and harmony in everyday life. When this is disrupted, such as in times of crisis, people in uncertaintyavoiding cultures "demand decisive leadership" to re-establish the order (Haruta and Hallahan 2003: 143). On the other hand, members of uncertaintyaccepting cultures, like the United States (46/100), tend to have a higher degree of acceptance for new ideas and a willingness to try something which deviates from "the norm," whether it pertains to consumer goods, business practices, or food. In general, people in uncertainty-accepting cultures are more likely to perceive change as positive and innovative, whereas people in uncertaintyavoiding cultures view change as dangerous and something to be avoided (Mooij and Hofstede 2011; Paul and Kapoor 2008).

Hofstede's cultural index provides a framework for operationalizing and analysing cultures on the macro (or national) level; however, there are certain limitations in its application. For one, its use implies that societies are relatively static and independent of each other. Briley (2009) suggests, in today's globalised world, "societies and the values that underlie them are increasingly interconnected and potentially dynamic, rather than coherent and stable" (183). Secondly, on a more micro level, individuals' values can shift from one moment to the next depending on the context of the situation at the time their values are elicited. In this sense, to truly understand consumer 
perception, motivation, and preference formation, we must also look beyond the macro-level of analysis and explore the cultural and ideological influences that impact individual consumption activity. To this end, this study relies on social identity theory, which postulates that people claim attributes that bring them closer to members of their own group (in-group) and distinguish them from the rest (out-group) (Tajfel and Turner 1979).

\section{Social Identity Theory}

Social identities are contextualised and refer to the component of one's selfconcept that is derived from actual or perceived membership in social groups. Social identities can be broad (e.g., gender, race, culture) or narrow (professor, athlete, mother). Identity profoundly shapes consumer behaviour (Alden et al. 2010; Markus and Kitayama 1991). Oyserman (2009a; 2009b), among other scholars (Belk 1988; Shavitt 1990; Shavit and Nelson 1999), suggests that "people routinely symbolize who they are and may become, as well as who they are not and want to avoid becoming, through consumption choices that can be self-symbolizing" (250). This concept is referred to as identity-based motivation, or the readiness to engage in identity-congruent action and to use identity-congruent mind-sets in making sense of the world (Oyserman 2007; Oyserman et al. 2006; Oyserman et al. 2007).

Social identities and consumer goods: In his research on the social identities that Myanmar urban residents display in public, Noack (2011) posits that "dress as visible identity in Myanmar is among the most important means to present who one is, what one aspires to, what one believes in and also what one is opposed to" (210). Dress can be used as a marker of identity in terms of ethnicity, religion, social class, gender, age and marital status, and is related to how one is perceived and treated. For instance, each Myanmar ethnic group has its own "national dress" to symbolise a unified ethnic identity. In that case, dress clearly acts to mark in-group membership (Tajfel and Turner 1979).

Noack (2011) also explores the identity conflicts young Myanmar urban residents may face in terms of social identities, especially for women, such as dressing modestly when representing an identity tied to their family and traditional societal expectations, versus dressing more fashionably when representing an identity tied to their own representation of gender and modern womanhood. If a member of a particular social identity/group violates ingroup social norms, he/she "risks, at best damaging [his/her] reputation, and at worst being avoided and ending up in social isolation" (Noack 2011: 203). 
The relationship between identity and consumerism is such that researchers have found that "aspects of identity that are temporarily made salient have been shown to influence consumer preference" (White and Argo 2009: 314). As Hannerz (1990) explains, consumers are often motivated to purchase brands that reinforce their membership in a specific global segment, such as a teenager, student, mother, and so forth; and/or purchase brands that reinforce their self-image such as intellectual, elegant, athletic, etc. The more important a particular identity is to an individual, the more attractive its associated products will be to that individual (Kleine et al. 1993).

In that context, it is not surprising that it has become common practice for companies to use identity-linking strategies in their marketing strategies. In other words, companies try to "link products and brands to target audience identities by highlighting relevant traits and characteristics, as well as gender, race-ethnicity, age, and culture-relevant values" (Oyserman 2009a: 276). These associations can be framed through product qualities as well as the terminology used to position the brand. Consider an advertising tagline from Secret deodorant- "Strong Like a Woman" or the classic slogan from Molson- "I am Canadian." These marketing campaigns highlight a connection between one aspect of the consumer's social identity and the brand (Bolton and Reed 2004; White and Argo 2009). Consumers' social identities can also be related to consumers' level of identification with their country, as illustrated with the latter example, or even their feelings towards other countries where consumer products are manufactured.

Ethnic identities in Myanmar: Myanmar is a very diverse country, with more than 135 different ethnic groups; Burmans/Barmars are the dominant ethnic group in Myanmar in general and in Myanmar cities in particular such as Yangon, which also include Indians, Chinese and other foreign residents (Dittmer 2010; Gravers 2014; Walton 2012). Ethnic identities represent particular socio-cultural norms to which their members adhere by (Holliday 2014; Walton 2012). Ethnic identities were one of the markers of difference during Myanmar's colonial period, and continue to be viewed as a "badge of resistance" against the central government, thus reinforcing the salience of ethnic group memberships and the socially constructed identities associated with such groups (Bünte 2016; Holliday 2014; Szep 2013; Walton 2012). Since Myanmar began its transition towards democracy, progress has been made to promote a more inclusive society with membership to the country as the main unifying identity group; a process that Walton (2012) describes as "an effective merging of ethnic and national identity" (21). 
However, as Holliday (2014) explains, ethnic identities "undergird a citizenship crisis that is one of the greatest challenges to the wider reform process" (412), as minority ethnic groups are expected to assimilate or at least conform to the majority ethnic group for the sake of national unity (Holliday 2014; Walton 2012). Indeed, the "difficulties in forming a coherent national identity" has hampered Myanmar's efforts to modernise the country (Dittmer 2010: 20), as ethnic minority groups continue to mistrust the central government, which is seen as only representing the interest of the ethnic majority group (Bünte 2016; Gravers 2014; Holliday 2014; Walton 2012). Holliday argues that Myanmar should adopt a policy that "moves away from ethnic hierarchy" and that instead "embraces the notion of a range of diverse ethnicities couched within a broad commitment to one nation" (418).

The discussion on ethnic identities in Myanmar also needs to take into account religious identities, as the two are often tied together. Myanmar, which as mentioned above has been marked by ethnic conflicts, has also witnessed violence by members of different ethnic/religious groups, mainly between Burman/Bamar Buddhists and Rohingya Muslims (Holliday 2014; Szep 2013; Thawnghmung 2014). Burman/Bamar Buddhists have claimed a "superior citizenship" status over Rohingya Muslims, and disagreements on Myanmar's pre-colonial borders and contemporary ones have led to questioning Rohingya Muslims' citizenship status, as well as that of other Muslims, and justifying violence against members of Muslim groups (Holliday 2014: 408). Religious conflicts have been particularly violent in recent years against Rohingya Muslims, who have been killed and driven from their homes by "Buddhist-led mob violence" (Szep 2013:2). As further discussed below, the conflict between Buddhists and Muslims is important to keep in mind because it directly affects Myanmar consumers' behaviour based on the religious identities of business owners. Indeed, consumers' social identities can lead to animosity based on the identities associated with a particular business and its products.

\section{Product Country of Origin, Consumer Ethnocentrism and Consumer Animosity}

Country of origin (COO) research explores what consumers feel when they are exposed to country of origin cues, how they form country images, and how such cues may influence their purchasing preference (e.g., Khan and Bamber 2008; Laroche et al. 2005; Verlegh et al. 2005). Nagashima (1970) defines country of origin images as "the picture, reputation, and/or stereotypes that consumers attach to products of a specific country. This image is created by 
such variables as representative products, national characteristics, economic and political background, history, and traditions" (68).

$\mathrm{COO}$ cues are operationalised through a number of extrinsic cues such as "made-in" labels, brand name, or packaging. One aspect of COO cues prominently featured in consumer behaviour studies is the perception that products manufactured in advanced western countries are more superior and higher quality than those from so-called developing countries (Bilkey and Nes 1982). These perceptions are largely attributed to the economic, cultural and political systems of the source countries (Wang and Lamb 1983). In other words, there is a positive correlation between perceptions of a particular country of origin and perceptions of the quality of this country's products (Okechuku 1994; Thakor and Katsanis 1996; Verlegh et al. 2005).

Scholars also suggest that, at times, awareness of a product's COO may induce some level of consumer ethnocentrism and/or consumer animosity, leading consumers to generate a preference for (or aversion to) domestic versus imported products from a specific country or region (e.g., Dmitrovic and Vida 2010; Ettenson and Klein 2005; Klein et al. 1998; Ouellet 2007; Russell and Russell 2006).

Consumer Ethnocentrism: Upadhyay and Singh (2006) explain ethnocentrism as a means of evaluating other cultures (out-groups) in relation to the standards of the culture a given individual belongs to (in-group). In this sense, ethnocentric consumers perceive their culture as superior and tend to perceive foreign-made products to be of poorer quality than those produced domestically (Hamin Elliot 2006; Wall et al. 1991). Another layer of consumer ethnocentrism relates to what extent consumers feel that buying foreign products is unpatriotic because of its adverse impact on local jobs and the national economy (Adorno et al. 1950). In this sense, consumers' motivation for purchasing domestic vs. imported goods has less to do with a sense of "superior culture" and more to do with supporting the collective.

Consumer Animosity: Consumer animosity relates to the relationship between consumers' feelings towards a country and consumer behaviour. Consumer animosity towards a country often stems from historical tensions between two countries in the form of war, territorial disputes, failed diplomatic relations, unequal economic or trade relations, religious conflict, etc. Nijssen and Douglas (2004) suggest that "economic animosity is more likely to be prevalent in small nations or economies, where the population may be discontent with the fact that their country's economy is dominated by a larger and stronger country" (2). Economic animosity may lead to general animosity 
and in turn to reluctance to buy products from the country in question (Nijssen and Douglas 2004; Russell and Russell 2006).

\section{Historical and Cultural Context of Myanmar}

Rampant ethnic strife and political turmoil led military regimes to seize power in 1962 and 1988, thrusting Myanmar into a half-century of self-imposed isolation. During its time in power, the military repressed political opposition, such as placing Aung San Suu Kyi, general secretary and co-founder of the National League for Democracy (NLD) opposition party, under house arrest in 1989, where she remained intermittently for 15 of the next 21 years. In response to reports of human rights abuses under the military regime, the United States, European Union member States, and other Western countries imposed partial or, in some cases, complete economic and military sanctions on Myanmar in 1990. Hence, "many Western companies, especially those dealing with consumer goods and those that had retail businesses pulled out of Myanmar" (Lwin et al. 2006: 455). Examples of United States economic sanctions included a prohibition on the import of Myanmar goods and a ban on United States investments in Myanmar (Kipgen 2016; Martin 2012).

Myanmar's future began to look up in 2011 when the military regime turned power over to a quasi-democratically elected president, Thien Sein. Since then, much to the surprise of the international community, the government has implemented a number of reforms supporting democracy and an open market economy. Thien Sein released political prisoners and allowed Aung San Suu Kyi and other opposition members to run for parliament. These shifts have been met by an easing of most Western sanctions on Myanmar, an increase in foreign direct investment and trade, and an expansion of multinational companies returning to city centres, such as Yangon and Mandalay, to do business, as “Myanmar's pariah status quickly abated as a parade of foreign leaders visited the country and eased sanctions" (Chow and Easley 2016: 522).

Aung San Suu Kyi won a seat in the national parliament, and, as mentioned above, Myanmar elected a civilian president, Htin Kyaw, in 2016, which led the United States to keep easing sanctions against Myanmar in order to further enhance trade relations between the two countries (Mohsin and Olorunnipa 2016). While Htin Kyaw holds the title of president, Aung San Suu Kyi has been described as "the most powerful person" in Myanmar (Fuller 2015: 4) and clearly stated that she "will be above the president" and that she "will run the government" (Mydans 2015: 5). 


\section{Current Socio-economic Context}

Consumer animosity in Myanmar: The often violent animosity between Buddhists and Muslims in Myanmar mentioned above led to the boycott of Muslim-owned businesses, mainly driven by the Buddhist monk-led "969 Movement" (Bünte 2016; Holliday 2014; Lall 2016). The 969 Movement has increased Burman/Bamar-Buddhist nationalism and anti-Muslim sentiments (Holliday 2014; Lall 2016; Szep 2013). As Holliday (2014) explains, a “chauvinistic Buddhist '969' movement is flourishing and many communities are aggressively adorned with Buddhist flags, with some also marked by 969 logos signalling an economic boycott of Muslim traders" (405-406). The 969 Movement's main message to its follower is as follows: "if you're eating, traveling or buying anything, do it with a Buddhist" (Szep 2013: 7).

Myanmar consumers have also expressed animosity towards China and its products. The overall animosity dates back to the late 1980s, when Myanmar started to heavily depend on China for trade, especially after Western countries imposed sanctions on Myanmar (Alamgir 2010; Lall 2016; Martin 2013; McCarthy 2010), and China became Myanmar's largest trading partner (Alamgir 2010; Chow and Easley 2016; Steinberg and Fan 2012). As the presence of Chinese companies in various industries such as construction, logging, mining and energy in Myanmar grew, Myanmar leaders and consumers expressed their dissatisfaction with the asymmetrical relationship between the two countries, perceiving China as "economically superior exploiters" (Noack 2011: 163) and a "threat to national sovereignty" (Chow and Easley 2016: 541). Myanmar consumers' unfavourable views of China and Chinese companies continued to grow (Hongwei 2014; Zin 2012) and resulted in an overall perception of a "socio-economic intrusion" of China into Myanmar (Zin 2012: 122).

Concomitantly, the export of low-quality and counterfeit products to Myanmar, along with a series of food safety scandals pertaining to Chinese products, strengthened Myanmar consumers' anti-Chinese sentiments and negative perceptions of Chinese products (Hongwei 2014). Myanmar consumers even expressed animosity towards Chinese businessmen, who were considered rude, "ignorant of local religions, culture and social customs," thus directly affecting transactions with Chinese-owned businesses and purchases of Chinese products (Hongwei 2014: 5). As an illustration of anti-Chinese sentiment, Zin (2012) uses the anecdote of a Myanmar couple being reluctant to sell their house despite a very high offer because they were concerned that the buyer would be Chinese. 
In contrast to those extremist approaches, Myanmar consumers can also use their purchasing power in less blatant, non-violent form, such as expressing political disapproval against the government by wearing certain types of clothing. For instance, "many young people discard 'traditional' dress in favour of something foreign precisely because the government does not want them to do so" (Noack 2011: 224).

Socio-economic development: In recent years, Myanmar's government has shown some signs of democratisation, especially in terms of technology and access to information, such as claiming to have put "a complete end to prepublication censorship" in 2012 (Bünte 2016: 285). More recently, the International Monetary Fund (2016) projected that Myanmar will be the world's fastest-growing economy in 2016, with a GDP growth of 8.6 percent that year.

Even though Myanmar's middle class is small compared to that of its neighbours (Bünte 2016), the "few international companies who did establish themselves and have opened one or several stores in Myanmar are very successful in selling their branded garments to those who can afford them and wear them very proudly," as years of isolationism made consumers desire foreign goods, which were themselves made popular by foreign movies and television shows from South Korea, the United States and Europe (Noack 2011: 147-148). For instance, Myanmar consumers in Yangon who identify as part of the young urban middle class use their buying power to follow the trend set by South Korean television shows as an expression of their modernity and status (Noack 2011).

Overall, Myanmar "has shown more hospitality toward foreign trade than other authoritarian regimes" (Alamgir 2010: 234). Indeed, the United States' bilateral economic ties with Myanmar have already grown significantly since the start of reforms in 2011. An American Chamber of Commerce chapter opened at the end of October 2013; United States exports to Myanmar grew from USD48.9 million in 2011 to USD227.1 million in 2015; while United States imports from Myanmar jumped from zero to USD143.8 million for the same period (United States International Trade Data 2016). Leading global companies that have recently entered Myanmar include (United States) CocaCola in 2012, (United States) PepsiCo in 2013, (Dutch) Carlsberg-Heineken in 2013, and (United States) Ford Motor Co. in 2013. Coca-Cola, CarlsbergHeineken, and PepsiCo have all established production facilities and bottling plants in Myanmar, helping to generate thousands of new jobs for local citizens.

As mentioned above, this study aims to explore attitudes towards globalisation of Myanmar consumers in Yangon and its relationship to their 
social identity. In addition, Coca-Cola is used in this study as an example of a globalised, United States product to investigate how Myanmar consumers in Yangon perceive a well-known United States brand sold in their country. Once sanctions were lifted, Coca-Cola was the first United States multinational corporation to re-enter Myanmar after more than 60 years. Not only has Coca-Cola been in Myanmar the longest, but it is also widely available and affordable for the average consumer.

\section{Present Study: Research Questions and Hypotheses}

In order to better understand how Myanmar consumers in Yangon conceptualise their culture, perceive products from different countries, and feel about globalisation, this study aims to answer the following research questions and test the following hypotheses:

RQ1: What are Myanmar consumers' cultural values based on Hofstede's dimensions of national cultures?

RQ2: What is the relationship between Myanmar consumers' social identity and their purchase intentions and perceptions of products based on country of origin?

H1a: There will be a positive relationship between Myanmar consumers' social identity and their likelihood to purchase Myanmar products.

H1b: There will be a positive relationship between Myanmar consumers' social identity and their perceptions of Myanmar products.

RQ3: What is the relationship between Myanmar consumers' social identity and their attitudes towards globalisation?

RQ4: What is the relationship between Myanmar consumers' social identity and their perceptions of Coca-Cola?

H2: There will be a positive relationship between Myanmar consumers' attitudes towards globalisation and their perceptions of Coca-Cola. 


\section{RESEARCH METHOD}

\section{Overview}

This study is intended to provide preliminary insights into the influence of Myanmar culture and social identity on consumer preferences. All participants lived in Yangon, Myanmar's largest city (about 5.2. million people). Yangon is also Myanmar's most cosmopolitan city due to the presence of international institutions and has some of the best infrastructure in the country that facilitates the commerce of consumer goods from western and other Asian countries (Noack 2011). Participants took part in a survey, either online or in person, approved by the institutional review board. All participants agreed to a consent form prior to proceeding to the survey, and all data were collected in Yangon from 10 September 2014 through 30 November 2014. Participants were recruited online and in person using network, snowball and convenience sampling techniques, thanks to the help of a strong network of personal contacts living in Yangon. Participants could choose to complete the survey questionnaire either in English or Burmese (Myanmar's main official language). Resource limitations, coupled with low-internet access in Myanmar, restricted the overall scope of participant recruitment and data collection in Yangon. The World Bank (2015a) reported that only 21.8 percent of Myanmar's population were internet users. Indeed, nearly all of the survey questionnaires were distributed to participants on paper and manually entered into an online data collection software.

\section{Participants}

A total of 301 participants completed the survey. For the present study, only participants who self-reported Myanmar nationality $(\mathrm{N}=268)$ were retained for analysis. Of these 153 (57.10 percent) were women and 112 were men (41.8 percent). Three participants did not report their gender. Participants' age ranged from 18 to $62(M=31.07 ; S D=7.99)$. Participants ranged from university students, to low-wage factory workers, to middle and upper class citizens with diverse professional backgrounds. Overall, participants were well educated. Only 35 (13.06 percent) reported high school as their highest level of education, whereas 146 (54.5 percent) held a bachelor's degree from a Myanmar government university and 45 (16.80 percent) had received a master's degree from a Myanmar government university. Other participants had studied at international universities in Myanmar $(n=18 ; 6.71$ percent $)$ or at universities outside of Myanmar ( $n=21 ; 7.82$ percent). Three participants 
did not report their educational level. Women were more likely than men to have a college degree $(X(1)=7.70, p<0.01)$. However, there were no gender differences for having studied outside of Myanmar.

Participants also varied in terms of annual income. Of the income brackets used, the lowest (less than 600,000 MMK [USD600]), and highest (more than 7, 600, 000 MMK [USD7,600]) brackets, each had more participants ( $n=49 ; 18.3$ percent and $n=47,17.5$ percent, respectively) than the intermediate brackets. Overall, participants' median annual income was between 2,600,000 MMK (USD2,600) and 3,600,000 MMK (USD3,600), which is higher than Myanmar's average annual income of USD1,280 (World Bank, 2015b), as is to be expected for residents of the country's largest city. There were no gender differences for participants' income. The majority of participants lived with their parents ( $n=188 ; 70.1$ percent). Similarly, the majority of participants ( $n=207 ; 77.2$ percent) had never lived or worked outside of Myanmar. Of those who $\operatorname{did}(n=61 ; 22.8$ percent), the two most popular countries were Singapore ( $n=23 ; 37.7$ percent) and Australia $(n=8 ; 13.1$ percent). There were no gender differences for participants' living situation or having lived or worked abroad.

\section{Measurement}

Cultural dimensions: As mentioned above, four aspects of Hofstede's cultural dimensions were explored in this study: high vs. low power distance, individualism vs. collectivism, uncertainty avoidance vs. acceptance, and masculinity vs. femininity. Participants rated their level of agreement with one statement per dimension based on Hofstede's (2001) cultural dimension scale (from $1=$ strongly disagree to $5=$ strongly agree). The statements were:

"In general, everyone in my community has equal power (or authority) and status" (high vs. low power distance); "Group loyalty (either at school, at home, or in the workplace) is more important than individual success" (individualism vs. collectivism); "It is important to have instructions and procedures in place to guide everyday life" (uncertainty avoidance vs. acceptance); and "Quality of life and happiness are more important than material or monetary success" (masculine vs. feminine).

Social identity: Participants' social identity was measured by adapting the three items from Cheek and Briggs' (2013) Aspect of Identity Questionnaire that dealt specifically with social identity. Participants rated how important the statements were in their life (from $1=$ not important at all to $5=$ Very important). The statements were: "My social behaviour, such as the way I act 
when meeting people"; "My participation in Burmese culture and customs" and "My identity as a Burmese person."

Country of origin consumer preferences: Ten countries were selected based on their proximity to Myanmar and current market penetration: Bangladesh, China, Great Britain, India, Japan, Myanmar, South Korea, Thailand, United States, and Vietnam. For each of the 10 countries, participants were asked to rate how likely they would be to purchase products from that country (from 1 = very unlikely to $5=$ very likely), as well as rate their perceived quality of products from that country (from 1 = very low quality to $5=$ very high quality).

Attitudes towards globalisation (global-mindedness): Globalmindedness was measured with six items adapted from Cleveland and Laroche's (2007) Acculturation to Global Consumer Culture (AGCC) scale. Participants rated their level of agreement with statements such as "Globalisation is generally a good thing"; "I pay attention to the fashion trends of people in my age group that live in other countries" and "I am excited for new multinational companies to establish business in Myanmar" (from 1 = strongly disagree to $5=$ strongly agree).

Perceptions of Coca-Cola: Six statements similar to the AGCC ones were created to measure participants' perceptions of and consumption of CocaCola. Statements included, "I have a positive image of the Coca Cola brand in Myanmar"; "I am familiar with Coca Cola's corporate social responsibility initiatives in Myanmar" and "I would recommend Coca Cola to my friends and family."

Demographic measures: Participants were asked to identify their nationality, gender, age, education level, living situation, income, and if they had lived or worked outside of Myanmar.

Data analysis: Data were analysed using SPSS version 22. Composite scores were created for the following variables: social identity $(\alpha=0.69)$, global-mindedness $(\alpha=0.71)$ and perceptions of Coca-Cola $(\alpha=0.79)$. Data analysis mainly relied on descriptive statistics, $t$-Tests to explore potential gender differences, and correlations among variables pertaining to participants' cultural values, social identity and consumer preferences to test the hypotheses, as well as to explore potential relationships between participants' age and income, and their responses.

As results are presented, it is important to keep in mind that all data were collected in Yangon. Therefore, results represent an exploratory insight into the social identity and consumer preferences of a sample of Yangon residents, most of whom are college educated and belong to Myanmar's middle 
class. While such demographic characteristics may not be representative of Myanmar's population in general and rural residents in particular, participants in this study may be more representative of the type of consumers international companies/marketers are aiming to target. Indeed, recognising that "Myanmar's rapid economic ascent and its equally fast growth in consumption have captured the attention and imaginations of many consumer products and retail companies" (Deloitte 2016: 3), Deloitte conducted a survey of Myanmar consumers with 200 households in Yangon and 150 households in Mandalay, the country's two largest commercial city-centres.

\section{RESULTS}

\section{Cultural Dimensions}

RQ1 asked what Myanmar consumers' cultural values are based on Hofstede's dimensions of national cultures. Descriptive statistics revealed that Myanmar consumers who took part in this study reported leaning towards a high power distance $(M=3.40, S D=1.10)$, suggesting that they accept and expect that power is distributed unequally.

Consumers also reported a high level of collectivism $(M=4.14$, $S D=0.81)$, suggesting that consumers perceive themselves and act predominantly as members of a cohesive group or community.

Consumers' answers to the masculine vs. feminine cultural dimension suggested that Myanmar culture is more feminine $(M=4.27, S D=0.78)$, suggesting that quality of life and happiness are more valued than competition and success.

Lastly, consumers reported a high level of uncertainty avoidance $(M=3.88, S D=0.71)$, suggesting that their daily life is guided by spoken and unspoken social rules which help maintain harmony and order.

A series of independent sample $t$-Tests for each cultural dimension conducted based on consumers' gender revealed no significant differences, thus suggesting that both Myanmar men and women felt the same way about their culture. However, consumers' age and income were related to two cultural dimensions: power distance and masculinity/femininity.

There was a significant positive correlation between power distance and age $(r=0.13, p<0.05)$, and between power distance and income $(r=0.16$, $p<0.01)$. That is, the older consumers were and the more income they had, the more likely they were to accept and expect that power is distributed unequally. 
Similarly, there was a significant positive correlation between the masculinity/femininity cultural dimension and age $(r=0.21, p<0.001)$, and between the masculinity/femininity cultural dimension and income $(r=0.21$, $p<0.001)$. The older consumers were and the more income they had, the more likely they were to value quality of life and happiness over competition and success. No other significant correlations were found between participants' age and income and the other two cultural dimensions (individualism/collectivism and uncertainty avoidance).

\section{Social Identity and Country of Origin}

RQ2 asked about the relationship between Myanmar consumers' social identity and their purchase intentions and perceptions of products based on country of origin. Overall, consumers reported high levels of identification with Myanmar culture $(M=3.98 ; S D=0.73)$. No difference was found between men and women, and no relationships were found between consumers' age and income and their social identity. Consumers reported that they would be most likely to purchase products (overall mean above 4.00) from Myanmar $(M=4.26$, $S D=0.85)$, Thailand $(M=4.18, S D=0.69)$ and Japan $(M=4.09, S D=0.76)$. Participants rated their likelihood to purchase products from the United States fourth out of 10 countries $(M=3.97, S D=0.94)$.

A series of correlations between consumers' social identity and their likelihood to purchase a product from a particular country were conducted. There was a significant positive correlation between consumers' level of social identity and their likelihood to purchase Myanmar products $(r=0.18$, $p<0.01$ ). No other significant correlations were found between consumers' level of social identity and their likelihood to purchase products from other countries.

A series of independent sample $t$-Tests were conducted for each country based on consumers' gender to explore potential gender differences in terms of purchase intentions. Results revealed only one significant difference for products from Bangladesh. Women $(M=2.01, S D=1.09)$ were significantly more likely than men $(M=1.75, S D=0.99)$ to be willing to buy Bangladeshi products $(t(261)=-1.98, p<0.05)$. No other significant differences were found for the other nine countries.

There was also a significant positive correlation between age and income and consumers likelihood to purchase products from India $(r=0.24$, $p<0.001$ and $r=0.14, p<0.05$, respectively). In addition, there were significant positive correlations between consumers' income and their 
likelihood to purchase products from South Korea $(r=0.18, p<0.01)$, Japan $(r=0.16, p<0.01)$ and Great Britain $(r=0.13, p<0.05)$.

In terms of perceptions of product based on country of origin, consumers gave the highest quality (overall mean above 4.00) for products from the United States $(M=4.52, S D=0.61)$, Japan $(M=4.29, S D=0.67)$ and Great Britain $(M=4.14, S D=0.71)$. Participants rated the quality of Myanmar products eighth out of 10 countries $(M=2.79, S D=0.76)$.

A series of correlations between consumers' social identity and their perceptions of product quality based on country of origin were conducted. No significant correlations were found for any of the 10 countries, suggesting that consumers' social identity does not influence their perceptions of product quality based on the products' country of origin. However, a marginal positive correlation was found between consumers' social identity and their perceptions of Myanmar products $(r=0.10, p=0.091)$.

A series of independent sample $t$-Tests were also conducted for each country based on consumers' gender to explore potential gender differences in terms of perceptions of product quality. Results revealed significant differences for products from three countries. For these three countries, women perceived the quality of products significantly higher than men: Bangladesh $(M=2.29$, $S D=0.83$ versus $M=1.85, S D=0.79)(t(261)=-4.34, p<0.001)$; Vietnam $(M=2.29, S D=0.83$ versus $M=1.85, S D=0.79)(t(261)=-2.61, p<0.01)$; and Myanmar $(M=2.98, S D=0.67$ versus $M=2.76, S D=0.65)(t(225.39)$ $=-3.32, p<0.01)$.

Consumers' age also affected their perceptions of product quality based on country of origin, as there were significant positive correlations between age and quality perceptions for products from Myanmar $(r=0.12, p<0.05)$ and Great Britain $(r=0.13, p<0.05)$. Lastly, the only significant correlation between consumers' income and quality perception was a negative correlation for products from Vietnam $(r=-0.12, p<0.05)$.

H1a stated that there will be a positive relationship between Myanmar consumers' social identity and their likelihood to purchase Myanmar products. The significant positive correlation reported above between the two variables supports the hypothesis, thus suggesting that higher levels of social identity are related to higher purchase intentions of Myanmar products.

H1b stated that there will be a positive relationship between Myanmar consumers' social identity and their perceptions of Myanmar products. The marginal positive correlation reported above between the two variables partially supports the hypothesis. 


\section{Attitudes Towards Globalisation}

RQ3 asked about the relationship between Myanmar consumers' social identity and their attitudes towards globalisation. Overall, consumers reported above average favourable perceptions towards globalisation $(M=3.59$, $S D=0.51)$. An independent sample $t$-Test revealed that women $(M=3.65$, $S D=0.53)$ displayed significantly higher levels of global-mindedness than men $(M=3.51, S D=0.47)(t(262)=-2.23, p<0.05)$. No relationships were found between consumers' attitudes towards globalisation, and their age and income. A correlation between social identity and global-mindedness revealed no significant results, suggesting that consumers' social identity is not related to their attitudes towards globalisation.

RQ4 asked about the relationship between Myanmar consumers' social identity and their perceptions of Coca-Cola. Overall, consumers reported neither favourable nor unfavourable perceptions towards Coca-Cola $(M=3.00, S D=0.66)$. An independent sample $t$-Test revealed no gender difference between men and women's perceptions of Coca-Cola. Similarly, no relationship was found between consumers' perceptions of Coca-Cola and their age. However, there was a significant negative correlation with participants' income $(r=-0.17, p<0.01)$. A correlation between social identity and CocaCola perceptions only revealed a marginal positive correlation $(r=0.11$, $p=0.088$ ), suggesting there may be a relationship between consumers' social identity and their perceptions of Coca-Cola.

H2 stated that there will be a positive relationship between Myanmar consumers' attitudes towards globalisation and their perceptions of CocaCola. A correlation between the two variables revealed a significant positive correlation $(r=.15, p<0.05)$, suggesting that higher levels of globalmindedness are related to more favourable perceptions of Coca-Cola, thus supporting the hypothesis.

\section{DISCUSSION}

The main purpose of this study was to investigate the influence of cultural values and social identity on the preferences of Myanmar consumers in Yangon. It aimed to understand the role Myanmar identity plays on consumers' perceptions of products based on country of origin and attitudes towards globalisation. As more and more United States companies are conducting business with Myanmar and establishing facilities in the country, it has become 
vital to understand Myanmar consumers and how their culture may influence their consumer preferences.

\section{Cultural Dimensions}

Hofstede's cultural dimensions offer some relevant insights into Myanmar culture, as consumers reported cultural traits associated with high power distance, collectivism, femininity, and uncertainty avoidance. Such findings are similar to how other Southeast Asian countries rank on Hofstede's cultural dimensions (The Hofstede Centre n.d.). Based on these findings, marketing and communication practitioners would be well-advised to tailor their messages to reflect social status (high power distance), importance of group loyalty and social relationships (collectivism), quality of life and happiness (femininity), and familiar, socially accepted behaviours and/or activities (uncertainty avoidance).

Consumers' gender did not affect their cultural values. However, two cultural dimensions were related to consumers' age and income: power distance and masculinity/femininity. The relationship between age and power distance may suggest that older generations are more accepting of unequal distribution of power in society. This is likely related to the hierarchal nature of Myanmar society, in which children are taught from a young age to be obedient towards their elders. Children accept that they are unequal to their elders and vice versa the elders assume a position of superiority and expect to be treated accordingly. From that perspective, as Myanmar consumers grow old, so would their acceptance of power distance.

The difference in power distance based on consumers' age could also reflect a broader cultural distinction between generations, as younger generations, especially educated, middle-class consumers in Yangon who mostly took part in this study, have been more exposed to globalisation and have welcomed foreign products as a way to display non-traditional, more modern identities. Marketing research needs to keep exploring these consumers' attitudes towards power distance as they grow older to further investigate these potential trends. Power distance differences also hold true for people with higher social status in society. For example, in Myanmar and other Southeast Asian countries, monks are always seated higher than nonmonks and there are special greetings and vocabulary used to show signs of respect. Similarly, in formal business or governmental meetings in Myanmar, participants are always seated in rank-order in terms of who holds the highest position of power. 
Furthermore, wealth and prestige in Myanmar is concentrated in the hands of a few. There is a significant and visible gap between the wealthy and poor in Myanmar, which can be seen by the enormous mansions found in Yangon's "Golden Valley," the high-end luxury cars that drive alongside the old broken-down taxis and buses used by average citizens, and by the upscale restaurants and night clubs frequented by the young, wealthy generation. This study found a correlation between power distance and income, which suggests that the wealthier people in Myanmar accept a position of greater power and act in a way that reinforces the differences between the wealthy and poor. This is particularly important when it comes to the purchasing preferences and consumer behaviour of members of those social groups.

Regarding the masculinity/femininity cultural dimension, older and wealthier consumers placed more importance on feminine characteristics, which emphasise happiness over competition. As Myanmar culture encourages people to care for each other, older consumers may perceive ideas related to feminine characteristics, such as cooperation and caring, as more valuable because they expect their children to take care of them as they grow old. Similarly, wealthier consumers may place more importance focusing on happiness because of their economic comfort and/or stability, as opposed to other consumers who may prioritise competition and material success because of their lower socio-economic position.

\section{Social Identity and Country of Origin}

Overall, consumers reported high levels of identification with Myanmar culture. From a social identity perspective, identification with Myanmar culture was more salient than their gender identity, as no difference was found between men and women. Furthermore, even though women in this study were more likely than men to have a college degree, both men and women displayed high levels of social identity. Similarly, consumers' age and income did not affect their social identification with Myanmar culture. Consumers' social identity was related to their likelihood to purchase Myanmar products, which may reveal a certain level of consumer ethnocentrism, especially considering that consumers did not rate Myanmar products as being of high quality. This may also be related to the fact that Myanmar products are typically less expensive than foreign products, and with limited disposable income consumers may choose to purchase Myanmar products based on price. As the Deloitte Myanmar Consumer Survey states, "generally, Myanmar consumers prefer local products as they desire the familiarity and lower price points" (Deloitte 
2016: 16). However, there was no relationship between Myanmar consumers' social identity and their likelihood to purchase products from other countries, thus suggesting no particular consumer animosity, which can be interpreted as a positive sign for international companies doing or intending to do business in Myanmar.

Lastly, there was also no relationship between Myanmar consumers' social identity and their perceptions of product quality from other countries. In addition, consumers rated United States products as having the highest quality from a list of 10 countries. The relationship between consumers' social identity and their perceptions of the quality of Myanmar's product is not clear and needs to be further explored. Interestingly, Myanmar women rated Myanmar products as being of higher quality than Myanmar men did, even though, as mentioned above, all Myanmar consumers displayed similar levels of social identity and men and women were both as likely to purchase Myanmar products. Such findings need to be further explored in future studies.

\section{Attitudes towards Globalisation}

Overall, Myanmar consumers seem open to the idea of globalisation, which seems to be independent from their social identity, as well as their age and income, as no relationship was found among the variables. However, consumers' gender identity may influence their attitudes towards globalisation, as women displayed higher levels of global-mindedness than men. This may also be related to education, as women were more likely than men to have a college degree, which may have made them more open to outside products. Indeed, for the two countries for which gender differences were found in terms of purchase intentions (Bangladesh) and product perceptions (Bangladesh and Vietnam), women displayed more favourable attitudes than men.

This study also used Coca-Cola as an example of a United States brand/ product to explore consumers' perceptions toward it. Consumers' perceptions of Coca-Cola were neither favourable nor unfavourable, and were not related to consumers' social identity. These findings reinforce the ones presented above in terms of consumer preferences based on country of origin, as Myanmar consumers' attitudes towards globalisation and perceptions of Coca-Cola do not reveal any potential consumer animosity behaviour. However, the more income consumers had, the more likely they were to hold unfavourable perceptions of Coca-Cola. This may be related to the higher levels of power distance reported by wealthier consumers. As most people drink Coca-Cola, expressing unfavourable views of Coca-Cola and/or reporting not drinking 
Coca-Cola often may serve as a social differentiator for consumers who can afford more expensive and healthier drinks.

\section{CONCLUSION}

This study aimed to shed light on the role Myanmar consumers' cultural values and their social identity play in consumer preferences. Despite years of isolation, Myanmar consumers in Yangon appear open to globalisation and their cultural values do not seem to conflict with the idea of a globalized economy. Women displayed more favourable attitudes towards globalisation than men, which may be due to the fact that women who took part in this study were overall more educated than men, and more women reported having studied outside Myanmar. These gender differences towards globalisation need to be further explored in future studies, taking into account education as well as other variables that may be related to global mindedness, such as exposure to international brands and products, or fluency in other languages.

\section{Practical and Theoretical Implications}

Results based on Hofstede's cultural dimensions have practical implications for multinational companies that are, or plan to be, present in Myanmar. For instance, Myanmar consumers in Yangon displayed cultural traits exactly similar to the ones from Thailand, as well as several similar cultural traits to those of their neighbouring Southeast Asian countries. Therefore, international communication practitioners can learn lessons from successful campaigns in surrounding countries and apply them to Myanmar. In addition, Hofstede's cultural dimensions themselves provide important insights into Myanmar culture that can serve as the basis for developing messages that would resonate with Myanmar audiences. Communication practitioners would also be well-advised to disseminate their messages online, as international telecommunication companies began to provide mobile services in 2014, increasing access to SIM cards that were previously controlled by the government (Freedom House 2015). Access to Internet is thus being driven by mobile technologies, and companies should be present on these platforms to reach out to and communicate with Myanmar consumers more effectively.

Findings from this study also provide useful insights for multinational companies setting up operations in Myanmar that plan to employ locals in their workforce, a common trend for companies currently operating in Myanmar, such as Coca-Cola, Heineken and Chevrolet. Western managers should analyse 
problems and interact with their employees with respect to Hofstede's cultural dimensions to establish a thriving workforce in Myanmar. As a collectivist country with high power distance, Myanmar employees view themselves as subordinate and "unequal" to their managers and see one-on-one direct feedback or disagreeing with one's boss as disrespectful and disgraceful. Therefore, Western managers would benefit from utilising group dynamics to solicit feedback as opposed to one-on-one interactions. Furthermore, people in collectivist cultures tend to shy away from direct forms communication. In Myanmar, as in many Asian cultures, people will often say "yes" when they do not mean it because saying "no" directly can be seen as confrontational and impolite. Therefore, it is important for Western managers to use strategies to distinguish the "ambiguous yes" from the "genuine yes." Setting exact times for appointments, sending reminders, and following up with employees to ensure that they are on tract are a few good examples.

Understanding that Myanmar is a feminine culture, not driven by individual achievement and material success, Western managers should be cautious when setting targets and developing incentive schemes based on performance. Indirect communication is almost always preferred in Myanmar. Hence, if an employee in the marketing department is struggling to meet his/her targets, using phrases like "we need to improve" or "our marketing department needs to improve" will be better received than a direct phrase like "you need to improve." Once the problem is established as being collective (department-wide), a manager can then speak openly about how individual employees can help the group achieve its targets. Results from Hofstede's cultural dimensions suggest that a successful workplace in Myanmar is based on building personal relationships, establishing mutual trust, and celebrating group achievements. Multinational companies can benefit from such results, as any company that wishes to be successful in Myanmar must first establish a successful workplace.

From a theoretical perspective, findings reveal that Myanmar consumers in Yangon strongly identify with their national identity and that in-group identification is related to consumer ethnocentrism. At the macro level, consumers' age and income were more salient than their gender identity for two of the four cultural dimensions explored in this study: power distance and masculinity/femininity. In both cases, consumers' age and social class identity were related to more acceptance of power distance and femininity characteristics, two cultural traits associated with Myanmar culture. More research is needed to further investigate (1) why those identities were related to those dimensions, especially given that there were no gender differences, 
and (2) why those same identities did not seem to affect the other two cultural dimensions (individualism/collectivism and uncertainty avoidance). Findings from this exploratory study suggest that consumers' different types of identity can be of different salience levels based on social contexts, and the tenets of social identity theory offer a relevant framework to further explore the role those identities play. For instance, in the context of this study, segmenting consumers by age and income may be more important than segmenting them by gender. Lastly, consumers' social identity was mainly related to their perceptions of Myanmar products, thus suggesting that social identity may be a concept mostly salient for products that are directly related to consumers' ingroup identities and may not function as well for products related to out-group identities, such as products from other countries.

\section{Limitations}

Overall, findings from this study paint an optimistic picture of Myanmar and its consumers for multinational companies. These results are particularly relevant for these companies because the sample population of this study, mostly educated, middle class consumers living in Myanmar's largest city, would be the type of consumers multinational companies would be most likely to target to buy their products. However, this also represents a limitation of this study, as participants may not be representative of other Myanmar consumers who do not live in Yangon or in a large city. Even though results from Hofstede's cultural dimensions are similar to the ones from other Southeast Asian countries, it is important to keep in mind that participants were not recruited using a random sampling. For instance, participants' education level, the majority had a college degree, is not reflective of the broader Myanmar population. As Alamgir (2010) explains, "the regime spends only 1.4 percent of GDP on health and education, which is less than 50 percent of what the next poorest member of ASEAN spends" (251).

This study also only investigated Myanmar culture at a macro level, focusing on consumers' social identity, which may overlook consumers' individual differences. Future research should also take a more micro-level approach and explore consumers' personal identity. The use of "Burmese" as opposed to "Myanmar" in the questionnaire, especially when measuring social identity represents another limitation of this study. While the government changed the name of the country from "Burma" to "Myanmar" in 1989, claiming an effort to deemphasize the connection that "Burma" had with the majority "Burman" ethnic group, scholars have pointed out that "Myanmar" 
is a Burmese language word used to refer to the country (Walton 2013). Despite this, some non-Burman ethnic groups "prefer the new name as it is less associated with the Burman (or Barmar) majority ethnic group" (Dittmer 2010: 2).

This study also solely relied on quantitative data obtained from a crosssectional survey.Future research shoulduse qualitativemethods, such asin-depth interviews, to further explore the influence of Myanmar consumers' cultural values and social and personal identities on their consumer preferences. Lastly, due to its exploratory nature given the dearth of studies focusing on Myanmar consumers' preferences, this study mostly gathered data pertaining to Myanmar consumers' overall perceptions of and attitudes towards globalisation. CocaCola was used as one example of one product from one multinational company, but because Coca-Cola was the first United States multinational corporation to re-enter Myanmar and because Coca-Cola products are relatively affordable for the average consumers, the current ubiquity of Coca-Cola in Myanmar may limit its use in the study as a reflection of how consumers in Yangon feel about foreign, globalised products. Future research should therefore examine how Myanmar consumers perceive different types of products from different companies, as well as how consumers perceive the identity of those products and their perceived assimilation in Myanmar culture.

\section{ACKNOWLEDGMENTS}

We would like to thank Swezin Le and Ko Ko Lin for translating the questionnaire from English to Burmese, and for their assistance in recruiting participants. Thanks as well to Deloitte for sharing its "Myanmar Consumer Survey" report with us, and to the anonymous reviewers for providing extremely thoughtful and helpful comments.

\section{NOTES}

* Alana Rudkin is a strategic communications consultant based in Pittsburgh, PA. She graduated from American University in Washington DC (United States) with a BA in Public Communications with a minor in International Relations in 2012, and an MA in Strategic Communications in 2014. Alana worked for nearly four years in Public Diplomacy at the United States Department of State's Bureau of Educational and Cultural Affairs in Washington, DC, before taking a position as a Communication's Manager for The Coca-Cola Company in Yangon, Myanmar in 2015. Alana is an avid 
traveller and strong believer in the ability of cross-cultural communication to promote mutual understanding and peace.

** Joseph Erba is an assistant professor of strategic communication at the William Allen White School of Journalism and Mass Communications at the University of Kansas. He taught at American University in Washington DC and obtained his $\mathrm{PhD}$ in mass communication from the University of North Carolina at Chapel Hill. His research explores the intersection of identities, such race/ethnicity, class and gender, on message development and interpretation. He focuses on multicultural communication, examining how marginalised publics interpret media messages and how to enhance communication with these audiences in a culturally relevant manner.

\section{REFERENCES}

Adorno, T. W. et al. 1950. The authoritarian personality. New York: Harper and Row.

Alamgir, J. 2010. Maynmar/Burma: International trade and domestic power under an "isolationist" identity. In Burma Or Myanmar? The struggle for national identity, ed. Dittmer, L., 231-252. Singapore: World Scientific, https://doi. org/10.1142/9789814313650_0009.

Alden, D. L., He, Y. and Chen, Q. 2010. Service recommendations and customer evaluations in the international marketplace: Cultural and situational contingencies. Journal of Business Research 63 (1): 38-44, https://doi.org/10.1016/j.jbusres.2009.01.009.

Alden, D. L., Hoyer, D. W. and Lee, C. 1993. Identifying global and culture-specific dimensions of humor in advertising: A multinational analysis. Journal of Marketing 57 (1): 64-75, https://doi.org/10.2307/1252027.

An, D. and Kim, S. 2007. Relating Hofstede's masculinity dimension to gender role portrayals in advertising. International Marketing Review 24 (2): 181-207, https:// doi.org/10.1108/02651330710741811.

Bae, J. and Kim, S. 2013. The influence of cultural aspects on public perception of the importance of CSR activity and purchase intention in Korea. Asian Journal of Communication 23 (1): 68-85, https://doi.org/10.1080/01292986.2012.725174.

Belk, R. W. 1984. Cultural and historical differences in concepts of self and their effects on attitudes toward having and giving. Advances in Consumer Research 11: 754-763. . 1988. Possessions and the extended self. Journal of Consumer Research 15 (2): 139-168, https://doi.org/10.1086/209154.

Bilkey, W. and Nes, E. 1982. Country-of-origin effects on product evaluations. Journal of International Business Research 13 (1): 89-99, https://doi.org/10.1057/palgrave. jibs. 8490539 .

Bolton, L. E. and Reed, A. 2004. Sticky priors: The perseverance of identity effects on judgment. Journal of Marketing Research 41 (4): 397-410, https://doi.org/10.1509/ jmkr.41.4.397.47019.

Briley, D. A. 2009. Cultural influences on consumer motivations: A dynamic view. In Beyond Hofstede: Culture frameworks for global marketing and management, ed. Nakata, C., 181-197. London, United Kingdom: Palgrave Macmillan, https://doi. org/10.1057/9780230240834_9. 
Bünte, M. 2016. Myanmar's protracted transition. Asian Survey 56 (2): 369-391.

Bünte, M. and Dosch, J. 2015. Myanmar: Political reforms and the recalibration of external relations. Journal of Current Southeast Asian Affairs 34 (2): 3-19.

Cheek, J. M. and Briggs, S. R. 2013. Aspects of Identity Questionnaire (AIQ-IV). Measurement instrument database for the social science. http://www.midss.org/ sites/default/files/aiq.pdf (accessed 5 January 2016).

Chow, J. T. and Easley, L. E. 2016. Persuading pariahs: Myanmar's strategic decision to pursue reform and opening. Pacific Affairs 89 (3): 521-542, https://doi. org/10.5509/2016893521.

Cleveland, M. and Laroche, M. 2007. Acculturation to the global consumer culture: Scale development and research paradigm. Journal of Business Research 60 (3): 249259, https://doi.org/10.1016/j.jbusres.2006.11.006.

Deloitte. 2016. The Myanmar consumer survey: Golden land, golden opportunities. Report by Deloitte.

De Mooij, M. 2004. Consumer behavior and culture: Consequences for global marketing and advertising. Thousand Oaks, CA: Sage.

Dittmer, L. 2010. Burma vs. Myanmar: What's in a name? In Burma or Myanmar? The struggle for national identity, ed. Dittmer, L., 1-20. Singapore: World Scientific, https://doi.org/10.1142/9789814313650_0001.

Dmitrovic, T. and Vida, I. 2010. Consumer behaviour induced by product nationality: The evolution of the field and its theoretical antecedents. Transformations in Business and Economics 9 (1): 145-165.

Dubyne, D. 2010. Myanmar: Southeast Asia's last frontier for investment. Topics Magazine, Taipei American Chamber of Commerce. http://www.oilseedcrops.org/myanmarsoutheast-asias-last-frontier-for-investment/ (accessed on 5 January 2016)

Ettenson, R. and Klein, J. G. 2005. The fallout from French nuclear testing in the South Pacific. International Marketing Review 22 (1): 199-224, https://doi. org/10.1108/02651330510593278.

Foscht, T. et al. 2008. The impact of culture on brand perceptions: A six-nation study. Journal of Product and Brand Management 17 (3): 131-142, https://doi. org/10.1108/10610420810875052.

Fuller, T. 2015. After victory in Myanmar, Aung San Suu Kyi quietly shapes a transition. The New York Times, 21 December. http://www.nytimes.com/2015/12/22/world/ asia/after-victory-in-myanmar-aung-san-suu-kyi-quietly-shapes-a-transition.html (accessed 10 January 2016).

Freedom House. 2015. Freedom on the net: Myanmar. https://freedomhouse.org/report/ freedom-net/2015/myanmar (accessed 1 February 2016).

Gravers, M. 2014. Ethnic diversity, multiple conflicts. In Burma/Myanmar: Where Now?, ed. Gravers, M. and Ytzen, F., 149-172. Copenhagen: NIAS Press.

Hall, E. T. 1963. A system for the notation of proxemic behavior. American Anthropologist 65 (5): 1003-1026, https://doi.org/10.1525/aa.1963.65.5.02a00020. 1981. The silent language. New York: Doubleday.

Hamin Elliot, G. 2006. A less-developed country perspective of consumer ethnocentrism and country of origin effects: Indonesian evidence. Asia Pacific Journal of Marketing and Logistics 18 (2): 79-92, https://doi.org/10.1108/13555850610658246. 
Han, S. and Shavitt, S. 1994. Persuasion and culture: Advertising appeals in individualistic and collectivistic societies. Journal of Experimental Social Psychology 30 (4): 326-350, https://doi.org/10.1006/jesp.1994.1016.

Hannerz, U. 1990. Cosmopolitans and locals in world culture. In Global culture: Nationalism, globalization and modernity, ed. Featherstone, M., 237-252 Thousand Oaks, CA: Sage Publications, https://doi.org/10.1177/026327690007002014.

Haruta, A. and Hallahan, K. 2003. Cultural issues in airline crisis communications. Asian Journal of Communication 13 (2): 122-150, https://doi.org/10.1080/ 01292980309364841.

Hofstede, G. 1980. Culture's consequences: International differences in work-related values. Beverly Hills, CA: Sage Publications, https://doi.org/10.1080/00208825.1 983.11656358.

1983. National cultures in four dimensions: A research-based theory of cultural differences among nations. International Studies of Management \& Organization $13(1 / 2)$ : 46-74.

.1991. Cultures and organizations: Software of the mind. London, UK: McGrawHill. Sage Publication.

. 2001. Culture's consequences: Comparing values, behaviors, institutions and organizations across nations. Thousand Oaks, CA: Sage.

. 2011. Dimensionalizing cultures: The Hofstede model in context. Online Readings in Psychology and Culture 2 (1): 3-26, https://doi.org/10.9707/2307-0919.1014.

Hofstede, G. and Bond, M. H. 1988. The Confucius connection: From cultural roots to economic growth. Organizational Dynamics 16 (1): 4-21, https://doi. org/10.1016/0090-2616(88)90009-5.

Hofstede, G., Hofstede G. J. and Minkov, M. 2010. Cultures and organizations: Software of the mind, 3rd ed. New York: McGraw-Hill.

Holliday, I. 2014. Addressing Myanmar's citizenship crisis. Journal of Contemporary Asia 44 (3): 404-421, https://doi.org/10.1080/00472336.2013.877957.

Hongwei, F. 2014. Enmity in Myanmar against China. ISEAS Perspective 8: 1-8.

International Monetary Fund. 2016. World economic outlook. http://www.imf.org/external/ pubs/ft/weo/2016/01/pdf/text.pdf (accessed 30 November 2016)

Khan, H. and Bamber, D. 2008. Country of origin effects, brand image, and social status in an emerging market. Human Factors and Ergonomics in Manufacturing and Service Industries 18 (5): 580-588, https://doi.org/10.1002/hfm.20126.

Kipgen, N. 2016. Democratization of Myanmar. New York: Routledge.

Klein, J. G., Ettenson, R. and Morris, M. D. 1998. The animosity model of foreign product purchase: An empirical test in the People's Republic of China. Journal of Marketing 62 (1): 89-100, https://doi.org/10.2307/1251805.

Kleine, R. E., Kleine, S. S. and Kernan, J. B. 1993. Mundane consumption and the self: A social-identity perspective. Journal of Consumer Psychology 2 (3) 209-235, https:// doi.org/10.1016/S1057-7408(08)80015-0.

Kramsch, C. 2001. Intercultural communication. In The Cambridge guide to teaching English to speakers of other languages, ed. Nunan Carter, R., 201-206. London: Cambridge University Press, https://doi.org/10.1017/CBO9780511667206.030.

Lall, M. 2016. Understanding reform in Myanmar: People and society in the wake of military rule. London: C. Hurst \& Co. 
Laroche, M. et al. 2005. The influence of country image structure on consumer evaluations of foreign products. International Marketing Review 22 (1): 96-115, https://doi. org/10.1108/02651330510581190.

Lenartowicz, T. and Roth, K. 1999. A framework for cultural assessment. Journal of International Business Studies 30 (4): 781-789, https://doi.org/10.1057/palgrave. jibs.8490839.

Lwin, M., Pecotich, A. and Thien, V. 2006. Myanmar: Foreign brands trickling through. In Handbook of markets and economies: East Asia, Southeast Asia, Australia, New Zealand, ed. Schultz, C. J. and Peotich, A., 447-476. Armonk, New York: M.E. Sharpe.

Markus, H. R. and Kitayama, S. 1991. Culture and the self: Implications for cognition, emotion, and motivation. Psychological Review 98 (6): 224-253, https://doi. org/10.1037/0033-295X.98.2.224.

Martin, M. F. 2012. U.S. Sanctions on Burma. Current Politics and Economics of South, Southeastern, and Central Asia 21 (3/4): 373-425.

. 2013. Burma's political prisoners and U.S. sanctions. Current Politics and Economics of South, Southeastern, and Central Asia 21 (3/4): 351-371.

McCarthy, S. 2010. Burman and ASEAN: A marriage of inconvenience. In Burma Or Myanmar? The struggle for national identity, ed. Dittmer, L., 327-362. Singapore: World Scientific, https://doi.org/10.1142/9789814313650_0012.

Minkov, M. 2007. What makes us different and similar: A new interpretation of the World Values Survey and other cross-cultural data. Sofia, Bulgaria: Klasika y Stil Publishing House.

Mohsin, S. and Olorunnipa, T. 2016. U.S. eases sanctions on Myanmar to boost trade after election. Bloomberg, 17 May. http://www.bloomberg.com/politics/articles/201605-17/u-s-eases-sanctions-on-myanmar-to-boost-trade-after-elections (accessed 20 May 2016).

Mooij, M. 2010. Global advertising and marketing: Understanding cultural paradoxes, 3rd ed. Newbury Park: Sage Publications.

Mooij, M. and Hofstede, G. 2011. Cross-cultural consumer behavior: A review of research findings. Journal of International Consumer Marketing 23 (1): 181-192.

Moon, Y. S. and Chen, K. 2002. Gender portrayals in Hong Kong and Korean children's TV commercials: A cross-cultural comparison. Asian Journal of Communication 12 (2): 100-119, https://doi.org/10.1080/01292980209364825.

Mydans, S. 2015. Aung San Suu Kyi, long a symbol of dignified defiance, sounds a provocative note. The New York Times, 17 November. http://www.nytimes. com/2015/11/18/world/asia/myanmar-aung-san-suu-kyi.html (accessed 20 November 2015).

Nagashima, A. 1970. A comparison of Japanese and US attitudes towards foreign products. Journal of Marketing 34 (1): 68-74, https://doi.org/10.2307/1250298.

Nijssen, E. J. and Douglas, S. P. 2004. Examining the animosity model in a country with a high level of foreign trade. International Journal of Research in Marketing 21 (1): 23-38, https://doi.org/10.1016/j.ijresmar.2003.05.001.

Noack, G. 2011. Local traditions, global modernities: Dress, identity and the creation of public self-images in contemporary urban Myanmar. Berlin: Regiospectra. 
Okechuku, C. 1994. The importance of product country of origin: A conjoint analysis of the United States, Canada, Germany and the Netherlands. European Journal of Marketing 28 (4): 5-19, https://doi.org/10.1108/03090569410061150.

Ouellet, J. F. 2007. Consumer racism and its effects on domestic cross-ethnic product purchase: An empirical test in the United States, Canada, and France. Journal of Marketing 71 (1): 113-128, https://doi.org/10.1509/jmkg.71.1.113.

Oyserman, D. 2007. Social identity and self-regulation. In Handbook of social psychology, ed. Kruglanski, A. and Higgins, T., 432-453. New York: Guilford Press, https://doi. org/10.1016/j.jcps.2009.06.001.

. 2009a. Identity-based motivation and consumer behavior. Journal of Consumer Psychology 19 (1) 276-279, https://doi.org/10.1016/j.jcps.2009.06.001.

. 2009b. Identity-based motivation: Implication for action-readiness, procedural readiness and consumer behavior. Journal of Consumer Psychology 19 (3): 250260, https://doi.org/10.1016/j.jcps.2009.06.001.

Oyserman, D. et al. 2006. Fitting in matters: Markers of in-group belonging and academic outcomes. Psychological Science 17 (10): 854-861, https://doi.org/10.1111/j.14679280.2006.01794.x.

Oyserman, D., Fryberg, S. and Yoder, N. 2007. Identity-based motivation and health. Journal of Personality and Social Psychology 93 (6): 1011-1027, https://doi. org/10.1037/0022-3514.93.6.1011.

Paul, J. and Kapoor, R. 2008. International marketing: Text and cases. New Delhi: Tata McGraw-Hill Education.

Philipsen, G. 2003. Cross-cultural and intercultural communication. Thousand Oaks, CA: Sage Publications.

Population Reference Bureau. 2015. 2015 world population data sheet. http://www.prb. org/pdf15/2015-world-population-data-sheet_eng.pdf (accessed 10 January 2016).

Rarick, C. and Nickerson, I. 2008. Combining classification models for a comprehensive understanding of national culture: Metaphorical analysis and value judgments applied to Burmese culture. Journal of Organizational Culture, Communications and Conflict 12 (2): 9-19.

Russell, D. W. and Russell, C.A. 2006. Explicit and implicit catalysts of consumer resistance: The effects of animosity, cultural salience and country-of-origin on subsequent choice. International Journal of Research in Marketing 23 (3): 321-331, https:// doi.org/10.1016/j.ijresmar.2006.05.003.

Schwartz, S. H. 1992. Universals in the content and structure of values: Theory and empirical tests in 20 countries. In Advances in experimental social psychology, ed. Zanna, M., 1-65. New York: Academic Press, https://doi.org/10.1111/j.1540-4560.1994. tb01196.x.

1994. Are there universal aspects in the content and structure of values? Journal of Social Issues 50 (1): 19-45.

Sengupta, S. 1995. The influence of culture on portrayals of women in television commercials: A comparison between the United States and Japan. International Journal of Advertising 14 (4): 314-333, https://doi.org/10.1080/02650487.1995.1 1104622.

Shavitt, S. 1990. The role of attitude objects in attitude functions. Journal of Experimental Social Psychology 26 (2): 124-148, https://doi.org/10.1016/0022-1031(90)90072-T. 
Shavit, S. and Nelson, M. 1999. The social identity function in person perception: Communicated meanings of product preferences. In Why we evaluate: Function of attitudes, ed. Maio, G. and Olson, J., 37-57. Mahwah, NJ: Erlbaum.

Shaw, J. 2004. Out of Burma: Grassroots activism forces multinationals to end ties with the Burmese dictatorship. Multinational Monitor 25 (1/2): 17-19.

Soares, A., Farhangmehr, M. and Shoham, A. 2006. Hofstede's dimensions of culture in international marketing studies. Journal of Business Research 60 (1): 277-284.

Steenkamp, J. E. M. 2001. The role of national culture in international marketing research. International Marketing Review 18 (1): 30-44, https://doi. org/10.1108/02651330110381970.

Steinberg, D. I. and Fan, H. 2012. Modern China-Myanmar relations: Dilemmas of mutual dependence. Copenhagen: NIAS Press.

Szep, J. 2013. The war of the Rohingyas. Reuters, 8 April. http://www.pulitzer.org/ files/2014/international-reporting/reuters/04reuters2014.pdf (accessed 5 January 2016).

Tajfel, H. and Turner, J. 1979. An integrative theory of intergroup conflict. In Intergroup relations: Essential readings, ed. Hogg, M.A. and Abrams, D., 94-104. Philadelphia: Psychology Press.

Thakor, M. and Katsanis, L. 1997. A model of brand and country effects on quality dimensions: Issues and implications. International Consumer Marketing 9 (3): 79 100, https://doi.org/10.1300/J046v09n03_06.

Thawnghmung, A. M. 2014. Contending approaches to communal violence in Rakhine state. In Burma/Myanmar: Where now? ed. Gravers, M. and Ytzen, F., 323-340. Copenhagen: NIAS Press.

The Hofstede Centre. n.d. Country comparison. https://geert-hofstede.com/countries.html (accessed 15 January 2016)

Upadhyay, Y. and Singh, K. S. 2006. Preference for domestic goods: A study of consumer ethnocentrism. The Journal of Business Perspective 10 (3): 59-68, https://doi. org/10.1177/097226290601000306.

United States. International Trade Data. 2016. U.S. trade in goods with Burma. https:// www.census.gov/foreign-trade/balance/c5460.html (accessed 10 October 2016).

Van Everdingen, Y. and Waarts, E. 2003. The effect of national culture on the adoption of innovations. Marketing Letters 14 (3): 217-232, https://doi. org/10.1023/A:1027452919403.

Venaik, S., Zhu, Y. and Brewer. 2013. Looking into the future: Hofstede long term orientation versus GLOBE future orientation. Cross Cultural Management 20 (3): 361-385, https://doi.org/10.1108/CCM-02-2012-0014.

Verlegh: W., Steenkamp, J. B. E. and Meulenberg, M. T. 2005. Country-of-origin effects in consumer processing of advertising claims. International Journal of Research in Marketing 22 (2): 127-139, https://doi.org/10.1016/j.ijresmar.2004.05.003.

Wall, M., Liefeld, J. and Heslop, L. A. 1991. Impact of country-of-origin cues on consumer judgments in multi-cue situations: A covariance analysis. The Academy of Marketing Science 19 (2): 105-113, https://doi.org/10.1007/BF02726002.

Walton, M. J. 2012. The "wages of Burman-ness:" Ethnicity and Burman privilege in contemporary Myanmar. Journal of Contemporary Asia 43 (1): 1-27, https://doi.or $\mathrm{g} / 10.1080 / 00472336.2012 .730892$. 
Wang, C. K. and Lamb, C.W. 1983. The impact of selected environmental forces upon consumers' willingness to buy foreign products. Journal of the Academy of Marketing Science 11 (1): 71-83, https://doi.org/10.1007/BF02721862.

White, K. and Argo, J. 2009. Social identity threat and consumer preferences. Journal of Consumer Behavior 19 (3): 313-325, https://doi.org/10.1016/j.jcps.2009.03.007.

Wiles, J.A., Wiles, C.R. and Tjernlund, A. 1995. A comparison of gender role portrayals in magazine advertising: The Netherlands Sweden, and the USA. European Journal of Marketing 29 (11): 35-49, https://doi.org/10.1108/03090569510100696.

Wong, N. and Ahuvia, A. C. 1998. Personal taste and family face: Luxury consumption in Confucian and Western societies. Psychology and Marketing 15 (1): 423-441, https://doi.org/10.1002/(SICI)1520-6793(199808)15:5 percent3C423::AID-MAR2 percent3E3.0.CO;2-9.

World Bank. 2015a. Data: Internet users (per 100 people). http://data.worldbank.org/ indicator/IT.NET.USER.P2 (accessed 10 January 2016).

World Bank. 2015b. Data: Myanmar. http://data.worldbank.org/country/myanmar (accessed 10 January 2016).

Wuthnow, R. et al. 1984. Cultural analysis. New York: Routledge.

Ytzen, F. 2014. Preserving order amid change and developing change amid order. In Burma/ Myanmar: Where Now? eds Gravers, M. and Ytzen, F., 25-45. Copenhagen: NIAS Press.

Zhang, J. 2010. The persuasiveness of individualistic and collectivistic advertising appeals among Chinese generation-X consumers. Journal of Advertising 39 (3): 69-80, https://doi.org/10.2753/JOA0091-3367390305.

Zin, M. 2012. Burmese attitude toward Chinese: Portrayal of the Chinese in contemporary cultural and media works. Journal of Current Southeast Asian Affairs 31(1): 115131. 